\title{
Description and analysis of the debris flows occurred during 2008 in the Eastern Pyrenees
}

\author{
M. Portilla ${ }^{1,2}$, G. Chevalier ${ }^{1,3}$, and M. Hürlimann ${ }^{1}$ \\ ${ }^{1}$ Department of Geotechnical Engineering and Geosciences, Technical University of Catalonia, Barcelona, Spain \\ ${ }^{2}$ Geosciences Department - Faculty of Sciences, National University of Colombia, Bogotá, Colombia \\ ${ }^{3}$ Sediment Transport Research Group, Technical University of Catalonia, Catalonia, Barcelona
}

Received: 4 November 2009 - Revised: 26 April 2010 - Accepted: 12 May 2010 - Published: 30 July 2010

\begin{abstract}
Rainfall-triggered landslides taking place in the Spanish Eastern Pyrenees have usually been analysed on a regional scale. Most research focussed either on terrain susceptibility or on the characteristics of the critical rainfall, neglecting a detailed analysis of individual events. In contrast to other mountainous regions, research on debris flow has only been performed marginally and associated hazard has mostly been neglected.

In this study, five debris flows, which occurred in 2008, are selected; and site specific descriptions and analysis regarding geology, morphology, rainfall data and runout were performed. The results are compared with worldwide data and some conclusions on hazard assessment are presented.

The five events can be divided into two in-channel debris flows and three landslide-triggered debris flows. The inchannel generated debris flows exceeded $10000 \mathrm{~m}^{3}$, which are unusually large mass movements compared to historic events which occurred in the Eastern Pyrenees. In contrast, the other events mobilised total volumes less than $2000 \mathrm{~m}^{3}$. The geomorphologic analysis showed that the studied events emphasize similar patterns when compared to published data focussing on slope angle in the initiation zone or catchment area.

Rainfall data revealed that all debris flows were triggered by high intensity-short duration rainstorms during the summer season. Unfortunately, existing rainfall thresholds in the Eastern Pyrenees consider long-lasting rainfall, usually occurring in autumn/winter. Therefore, new thresholds should be established taking into account the rainfall peak intensity in $\mathrm{mm} / \mathrm{h}$, which seems to be a much more relevant factor for summer than the event's total precipitation.
\end{abstract}

\section{Correspondence to: M. Portilla}

(modesto.portilla@upc.edu)
The runout analysis of the 2008 debris flows confirms the trend that larger volumes generally induce higher mobility. The numerical simulation of the Riu Runer event shows that its dynamic behaviour is well represented by Voellmy fluid rheology. A maximum front velocity of $7 \mathrm{~m} / \mathrm{s}$ was backanalysed for the transit section and even on the fan velocities larger than $2 \mathrm{~m} / \mathrm{s}$ were obtained.

This preliminary analysis of the major Eastern Pyrenean debris flows represents the first background for future studies. Additional research on other events is necessary to support the results presented herein, and to properly assess and reduce hazard related to debris flows.

\section{Introduction}

In the Eastern Pyrenees, shallow landslides and debris flows are not as widely reported as in other mountainous catchments. However, they represent an important hazard that should be assessed. Until now, most of the descriptions or analyses focus on shallow landslides and have been carried out at regional scale, applying geographical information system (GIS) techniques (e.g. Baeza and Corominas, 2001; Santacana et al., 2003), inventory data (Gallart and Clotet, 1988) or other types of models (Bathurst et al., 2006). Additionally, the majority of these studies focuses on failures triggered during the catastrophic 1982 rainstorm. All this shows the lack of information and research on debris-flow initiation, flow behaviour and hazard in the Eastern Pyrenees. Only in the Principality of Andorra some analysis on debris-flow hazards has been carried out for urban planning purposes (Hürlimann et al., 2006).

During the summer of 2008, several mass movements occurred and caused important damages and economic losses in infrastructures in the Eastern Pyrenees. Finally, five debris

Published by Copernicus Publications on behalf of the European Geosciences Union. 

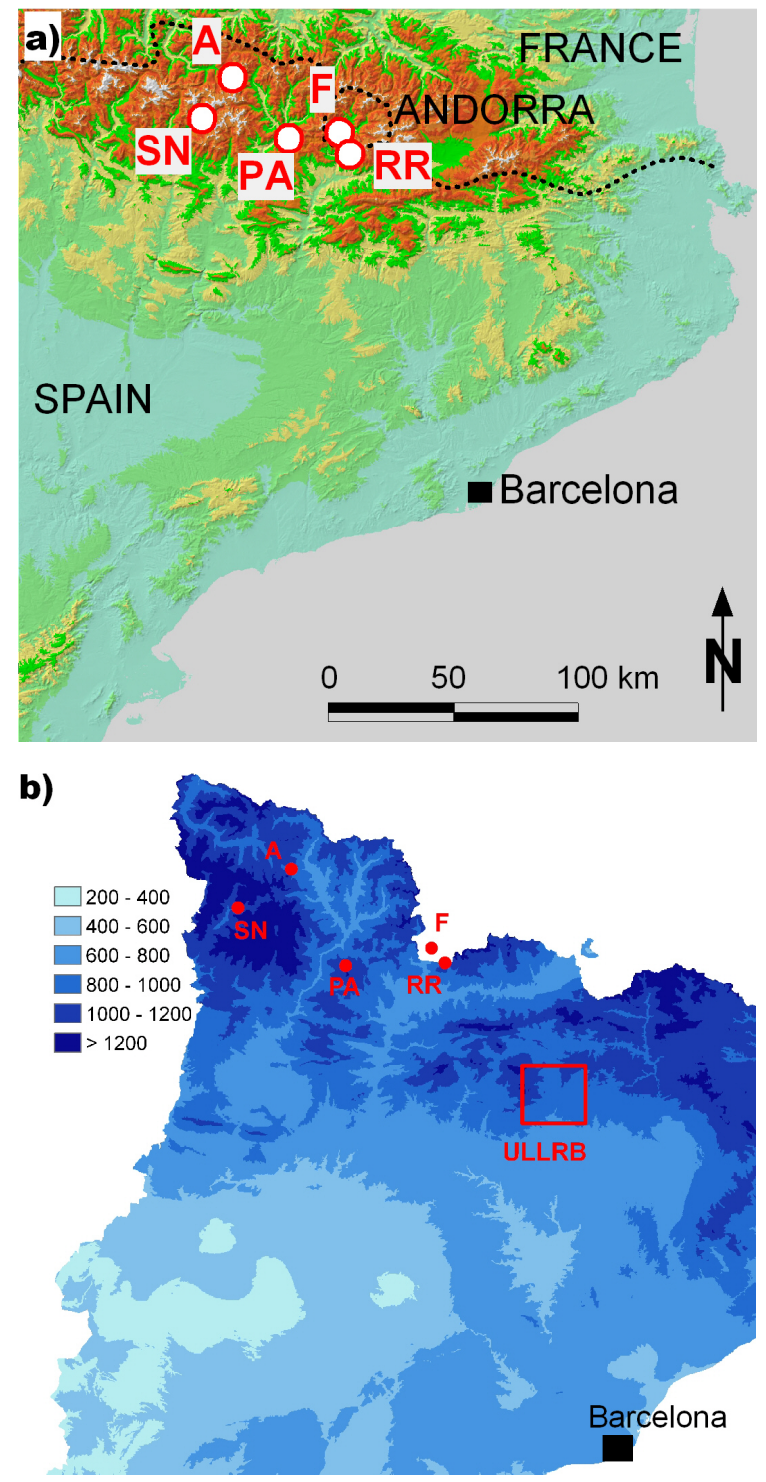

Fig. 1. (a) Location of the five debris flows, (b) Mean annual precipitation (in $\mathrm{mm}$ ) of Catalonia (Source: CAC, Climatic Atlas of Catalonia, http://www.meteocat.com/mediamb_xemec/servmet/, last access: 8 October 2009). (A: Andreuet, F: Fontanals del Pui, PA: Portainé, RR: Riu Runer, SN: Sant Nicolau, ULLRB: Upper Llobregat River Basin.)

flows were selected due to data availability (Fig. 1a). Moreover, all events involve a volume which is likely to produce damage on the fan area. The terminology of the process type used in this paper is in accordance with that of Hungr et al. (2001), while the distinction between in-channel generated debris flows and landslide triggered debris flow was applied as proposed by Coussot and Meunier (1996).

The main purpose of this study is the description and analysis of the most important parameters for hazard assessment of the selected events. First, the susceptibility, or geologic and morphologic conditions, are revised. Second, the trigger mechanism, which is intense rainfall, is analysed. And third, the runout, together with the dynamic behaviour of the mass movements, is studied. Additionally, the results are compared with events that occurred at other sites of the world in order to evaluate site-specific characteristics. Finally, the results of this research could support future studies and may furnish practitioners and stakeholders with important information to improve protection and to mitigate such hazards.

\section{General settings}

The Pyrenees are a mountain range that represents the natural boundary between France and Spain and enclaves the Principality of Andorra. It spreads on shore over $430 \mathrm{~km}$ on an East-West axis. The study area belongs to the Eastern Pyrenees.

The Pyrenees are old and young at the same time. Young because the uplift of the range started 40 millions years ago, and old because the material uplifted did not form at that time, but long before that (Muñoz, 1992; Teixell, 1998; ICC, 2003).

All our events occurred in the Axial Pyrenees, which are comprehensively described by ECORS Pyrenees Team (1988). The stratigraphy of our study area runs from Ordovician to Devonian with Tardi-Hercynian intrusions. The network of faulting is dense and complex, roughly following an ENE-WSW axis, but reported as showing little activity when compared to other ranges' exhumation rates (Fitzgerald et al., 1999; Lynn, 2005).

During the Pleistocene, the Axial Pyrenees were covered by glaciers and their great power of erosion formed cirques and U-shaped valleys. As a matter of fact, bedrock and tills are the most common outcrops in the study area. Not to be forgotten is the presence of colluviums, sometimes covering the mentioned units, thus, creating a discontinuous sequence of deposition.

The complex meteorology of the study area is due to its geographical position between the Mediterranean Sea and the Atlantic Ocean, as well as between continental and oceanic huge extensions. Moreover, its latitudinal situation inside a temperate climate zone leads to seasonal extreme variations (Cuadrat and Pita, 1997; Martín and Olcina, 2001; Servei Meteorològic de Catalunya ${ }^{1}$ ). For these reasons, the summer season is dry and the rest of the year is moderately humid, the highest precipitation being in autumn.

The relief of the field site ranges from sea level to over $3400 \mathrm{~m}$ above sea level (a.s.l.) (Aneto Peak). A high relief combined with prevailing winds, yields to weather contrasts as observed in the average annual rainfall (Fig. 1b). Precipitation can range from 850 to $1200 \mathrm{~mm} /$ year in the catchments, where the debris flows in 2008 took place.

\footnotetext{
${ }^{1}$ http://www.meteocat.com/, last access: 2 October 2009
} 
Table 1. Geomorphological parameters assessed by field work (volumes), topographic maps, aerial pictures, and archives. For Riu Runer and Portainé, maximum elevations correspond to the catchment's maximum elevation. For the others, maximum elevations refer to the landslide crown zone. The minimum elevation is always for the elevation of the fan's apex.

\begin{tabular}{lccccc}
\hline & Riu Runer & Fontanals del Pui & Portainé & Andreuet & Sant Nicolau \\
\hline Volume $\left(\mathrm{m}^{3}\right)$ & 14000 & 1500 & 26000 & 1000 & 1800 \\
Catchment area $\left(\mathrm{km}^{2}\right)$ & 8.2 & 0.2 & 5.5 & 0.029 & 0.26 \\
Catchment exposure & $\mathrm{W}$ & $\mathrm{ESE}$ & $\mathrm{N}$ & $\mathrm{S}$ & $\mathrm{S}$ \\
Maximum/minimum elevation (m a.s.l.) & $2150 / 885$ & $1240 / 950$ & $2400 / 975$ & $1975 / 1550$ & $1985 / 1480$ \\
Mean slope angle of fan $\left(^{\circ}\right)$ & 11 & 13 & 9 & 10 & 10 \\
Mean slope angle of channel $\left(^{\circ}\right)$ & 13 & 37 & 16 & 32 & 35 \\
Runout, $L(\mathrm{~m})$ & 5175 & 710 & 4400 & 890 & 995 \\
Vertical drop, $H(\mathrm{~m})$ & 1154 & 290 & 1155 & 425 & 505 \\
$H / L(-)$ & 0.22 & 0.41 & 0.26 & 0.48 & 0.51 \\
Melton ratio & 0.45 & 0.67 & 0.61 & 2.91 & 0.98 \\
\hline
\end{tabular}

\section{Event descriptions}

This section accounts for an interdisciplinary description of the investigated events. Geology, morphology, hydrology, elements at risk, process description and damages are reported. This part focuses first on in-channel debris flows. Then landslide triggered debris flows are tackled. Data used in this part are presented in Table 1, which were gathered through the study of aerial pictures and topographic map, as well as archives like newspapers or administrative reports and field work.

\subsection{In-channel generated debris flows}

\subsubsection{Riu Runer}

The Riu Runer catchment is located at the border of Spain and the Principality of Andorra (Fig. 1a) and drains a total area of $8.2 \mathrm{~km}^{2}$ (Fig. 2a). The bedrock in this area dates from Silurian and consists of slate (ICC, 2003). Most of the catchment area is overtopped by colluvial and fluvial glacial deposits.

The catchment is a place of pasture (upper part) and forest (lower/middle part) with little signs of human activity. The profile of the torrent's slope can be found in Fig. 3. Along its channel, only a few past lateral contributions of material (shallow landslides and/or banks destabilization) were observed.

On the evening of 1 August 2008, the Andorran Border Customs house was severely hit by a debris flow triggered by a short and intense thunderstorm. This debris flow seemed to be the result of the progressive incorporation of bed material within the channel due to a high discharge, since no traces of landslides are visible in the initiation area. The torrent in the upper reach (down to $2000 \mathrm{~m}$ a.s.l.; see Fig. 3) shows signs of moderate fluvial erosion (V-shaped channel erosion) and some deposition (small areas of accumulation of loose mate-
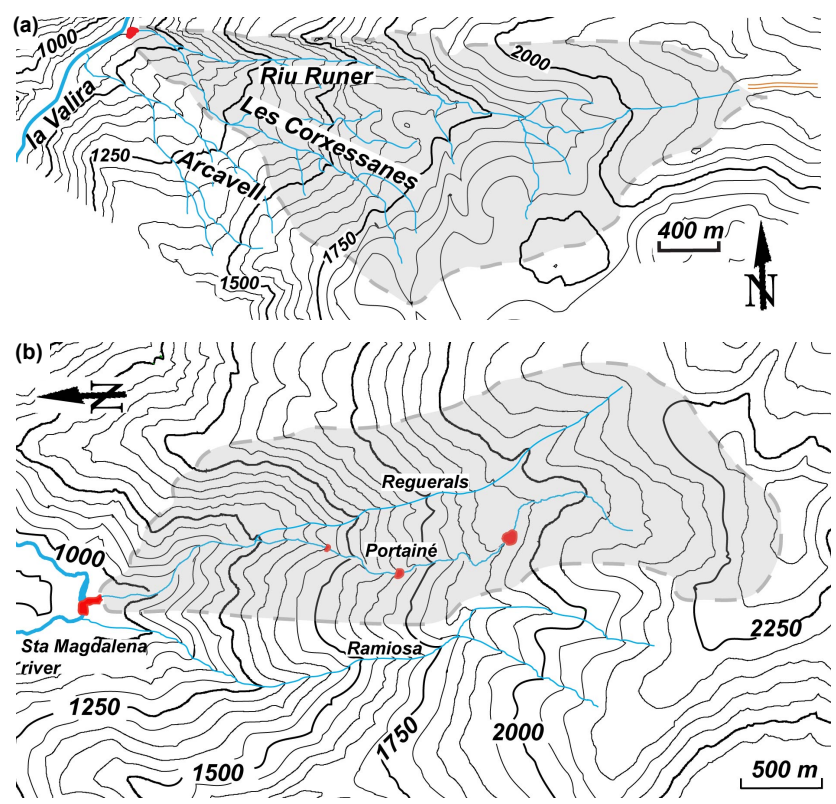

Fig. 2. Catchment maps of Riu Runer (a) and Portainé (b). The river courses are drawn wider than the torrents and both in light blue, in red depositional areas, and in grey the catchment surface. Contour intervals are every $50 \mathrm{~m}$.

rial). Below $2000 \mathrm{~m}$ a.s.l. the slope's steepness increases and the torrent shows a greater degree of activity and silent witnesses: lateral levees, scouring activity reaching the bedrock in numerous sections, deposition areas and wounds on trees because of boulder impacts. As the flow travelled down, the solid material content increased due to scouring, shallow lateral slides and incorporation of trees. In the channel, at the fan apex, there is a small number of one-to-two metre boulders in a sandy/gravelly matrix, with a little portion of fine material. 


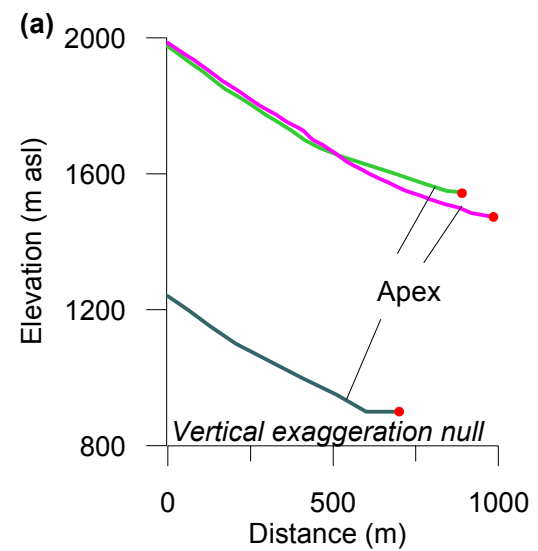

(b)
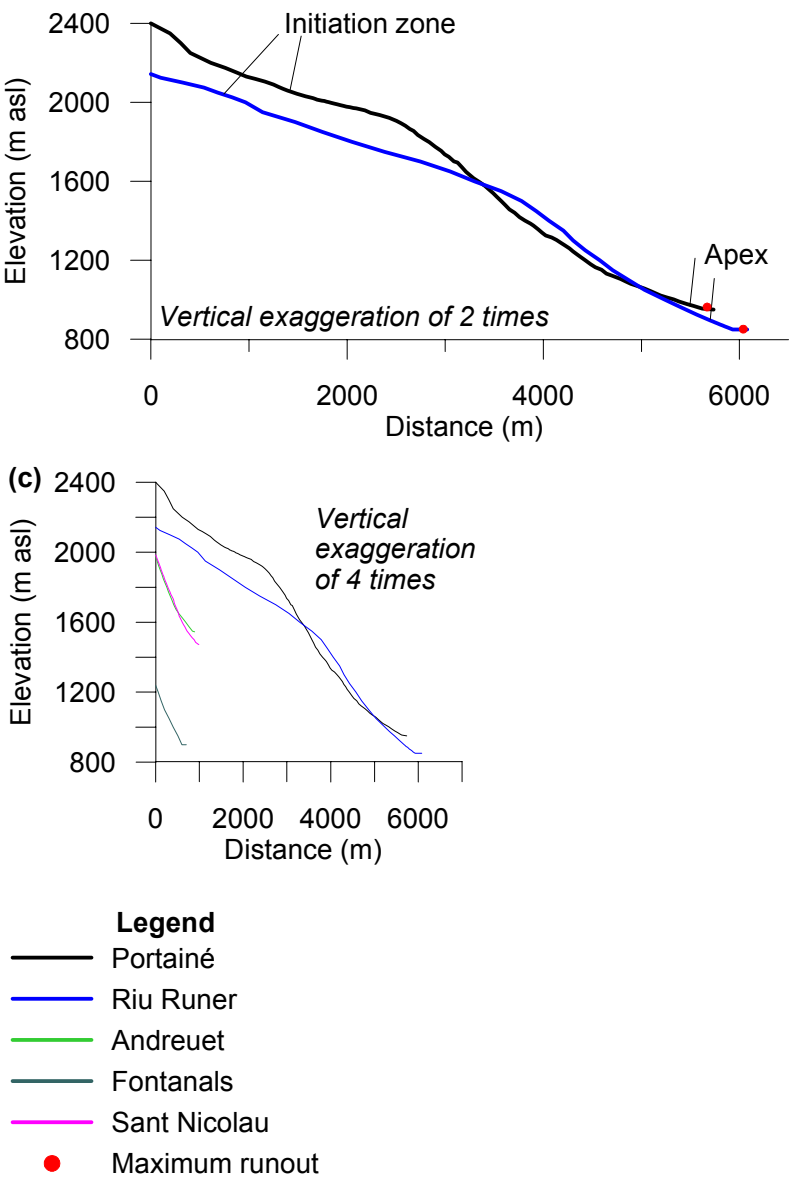

Fig. 3. Topographic profiles of (a) the landslide triggered debris flows (profiles start at the landslide's headscar), (b) the in-channel generated debris flows, and (c) both sorts of debris flows.

The deposit area starts just a couple of hundred metres upstream of the Andorran Border Customs house at the fan apex (900 m a.s.l.). Eventually the torrent channel could not drain the flow discharge; a culvert was obstructed, blocking the flow and forcing both material and trees to depose. The consequence was the accumulation of material partly burying buildings and cars present on site. The water supply in the near proximity was also disturbed, as two aqueducts present in the channel were destroyed. Fortunately no casualties were reported.

An estimate of the scoured material quantity, as well as contributions along the debris flow path, was carried out and cross-checked with the total volume of material deposited at the fan, which was estimated on field. Finally, the total volume of the debris flow was assumed to be $14000 \mathrm{~m}^{3}$ (Table 1).

\subsubsection{Portainé}

In the Portainé ski resort area, bedrock is the oldest outcropping in the Pyrenees, Cambrian to Ordovician in age (ICC, 2003), and consisting of sedimentary units made of pelite, sandstone and greywacke. To some extent colluviums and fluvio-glacial deposits overtop them.

The catchment consists of two main torrents, the Portainé torrent in the West and the Reguerals torrent in the East (Fig. 2b). The morphology of the basin can be divided into two parts: a smooth higher part, where the presence of rills can be observed; and a steep lower part, where well incised channels were formed (Fig. 3). In the steep section, the flanks of the torrents are unstable and lateral failures due to erosion of the slope's toe are recurrent but small (about several tens of cubic metres).

On the evening of 12 September 2008, a rainstorm hit the area and triggered one of the largest debris flows that took place in the Eastern Pyrenees. No clear initiation failure could be observed, thus, promoting the idea that the flow probably started by minor erosion along rills in the higher parts and transformed into a mature debris flow in the subsequent steep section of the torrent, where scouring rates of up to $\sim 10 \mathrm{~m}^{3} / \mathrm{m}$ led the bedrock to outcrop in some portions and the amount of material transported to considerably increase. Several secondary failures of adjacent slopes were also observed, which enlarged the total volume of the debris flow. Although the access road to the ski resort crosses the torrent in three distinct points and even though material deposition occurred at those points, as well as excessive failure of the road foundation, the main volume of the debris flow was deposited at the fan. Note the presence on the fan of an electric plant, including a dam and a retention lake, which was only marginally hit by the debris flow.

The total solid volume of the debris flow was estimated by assessing the volume of material built up on the fan and also a volume estimate of scoured material along the flow trajectory. Finally, a total volume of about $26000 \mathrm{~m}^{3}$ was assumed (Table 1). A detailed granulometric analysis of the debris-flow material was not possible, but two to three metre boulders in large proportion are visible in a gravel matrix, with a small fine fraction that could be observed in the lowest part of the flow trajectory. 
The Portainé's debris flow seems to have been affected by the presence of the previously cited structures related to human activity in the catchment. But the opposite is also true: 1) the ski resort faced profound reshaping of the surface, 2) roads were severely damaged, and 3) the electric plant facilities were superficially covered by an important volume of material.

\subsection{Landslide triggered debris flows}

\subsubsection{Fontanals del Pui}

Fontanals del Pui torrent is located in Andorra (Fig. 1a). The lithology of the site consists of Silurian slate and Quaternary slope debris, similar to the ones in Riu Runer catchment. However, a difference should be pointed out since no glacial features were exhibited. The vegetation on this slope is almost absent. There are only patches of shrubs in the scree.

The rainfall that triggered the Riu Runer's debris flow event had also consequences on the close neighbourhood. Some $5 \mathrm{~km}$ northward this rainfall induced the Fontanals del Pui event. This debris flow was triggered by a small failure of the scree in the middle of the catchment. The transit path downstream of this initiation point shows an alternation of erosion and no scouring (accumulation), which, due to the fact that trees had been bent and partially covered by fine sediments, suffered the action of the flow. As the flow crossed the road at the down part of the flow path, a first deposition area developed. There was still another area more downstream, where the same road is crossed again. The artificial channel downstream this point was mostly filled by sediments. The particle size mobilised by the debris flow was smaller than in the Riu Runer including mainly gravels and boulders no bigger than $50-70 \mathrm{~cm}$ across. Given the small magnitude of the debris flow $\left(\sim 1500 \mathrm{~m}^{3}\right)$, the urbanised area developed on the fan did not suffer important damages.

\subsubsection{Andreuet torrent}

In Andreuet's catchment (Fig. 1a), only metamorphic rocks made of slate and phyllite outcrop. They are covered, in the lower part, by colluvial material of metamorphic origin. Clay and gravels make up its grain size. The upper part of the catchment displays bushes and grass, while the lower part consists in trees and shrubs.

During the night, between 25 and 26 June 2008, a rainstorm induced a shallow landslide in the upper part of the catchment that developed into a debris flow. This flow began its erosional process when it reached the colluvium at midlength and deposited as soon as it hit the road present at the slope's toe. Within the torrent, lateral levees were observed and related to the last event.

\subsubsection{Sant Nicolau}

Sant Nicolau torrent is located close to the National Park in the Axial Pyrenees (Fig. 1a). Granitic rocks constitute the lithology outcropping in the catchment and are covered by colluvial material in the lower part of the catchment. Colluvium thickness is of a couple of metres in the fan area and increases to a few metres as it reaches the contact with the bedrock. Regarding the grain size of the colluvium, metresized boulders supported by a sandy matrix can be observed in the upper part of the torrent. At the lower part, boulders become gravels of a few tens of centimetres in general. The morphology of the torrent should be noted as it displays a straight, stretched and elongated path. The vegetation consists of bushes and grass in the upper part of the catchment and presents in the lower part, small trees and shrubs.

On 25-26 May 2008, a shallow landslide induced by heavy rainfall provoked a debris flow in the Sant Nicolau torrent. The flow propagated down the steep upper part (Fig. 3), without significant erosion or deposition. At the bedrockcolluvium contact, a major scouring was observed. Within the colluvium the flow was confined in the torrent and lateral levees were formed. The flow blocked the access road of the National Park and deposited most material on the fan.

\section{Morphologic analysis}

The literature provides examples of geomorphological characterisation of debris flows (e.g. Di Crescenzo and Santo, 2005). However, only very few focus on the Eastern Pyrenees (Gallart and Clotet, 1988; Corominas et al., 2002). That is why we have analysed two aspects of the five events described herein: one at catchment scale and the other focussing on the initiation area.

At catchment scale, magnitude (total volume) and area were assessed for each event based on field work, aerial pictures and topographical maps. Figure 4a displays their relationship. Limits published by D'Agostino and Marchi (2001) were added. They defined these limits using data on debris flows from 130 catchments observed in the Eastern part of the Italian Alps.

Then we propose the study of the initiation zone (Fig. 4b). In order to do so, the initiation point is defined, while two cases are recognised:

- When the debris flow originated from a landslide, the initiation point was chosen as the headscar.

- When the debris flow originated from bed fluidization, the initiation point was chosen as the beginning of the "channelization zone" (as defined in Di Crescenzo and Santo, 2005). On both concerned catchments (Portainé and Riu Runer), this point coincides with a significant scouring. 


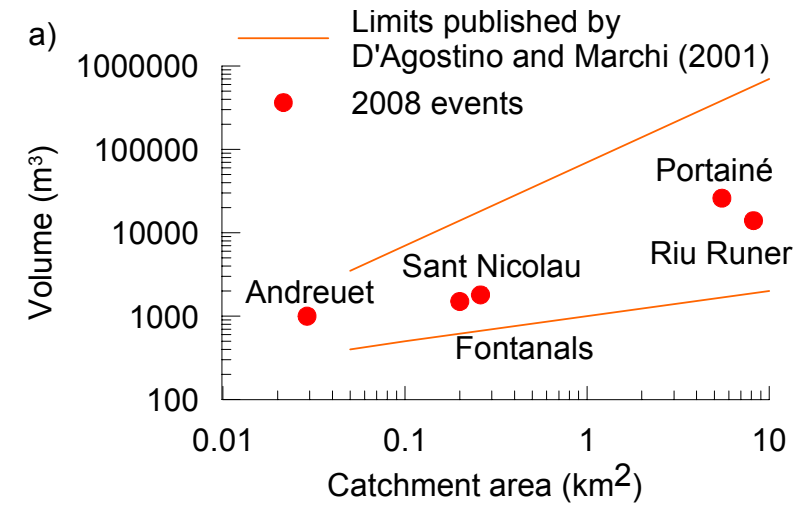

b) $\quad r_{-}$Shannel erosion
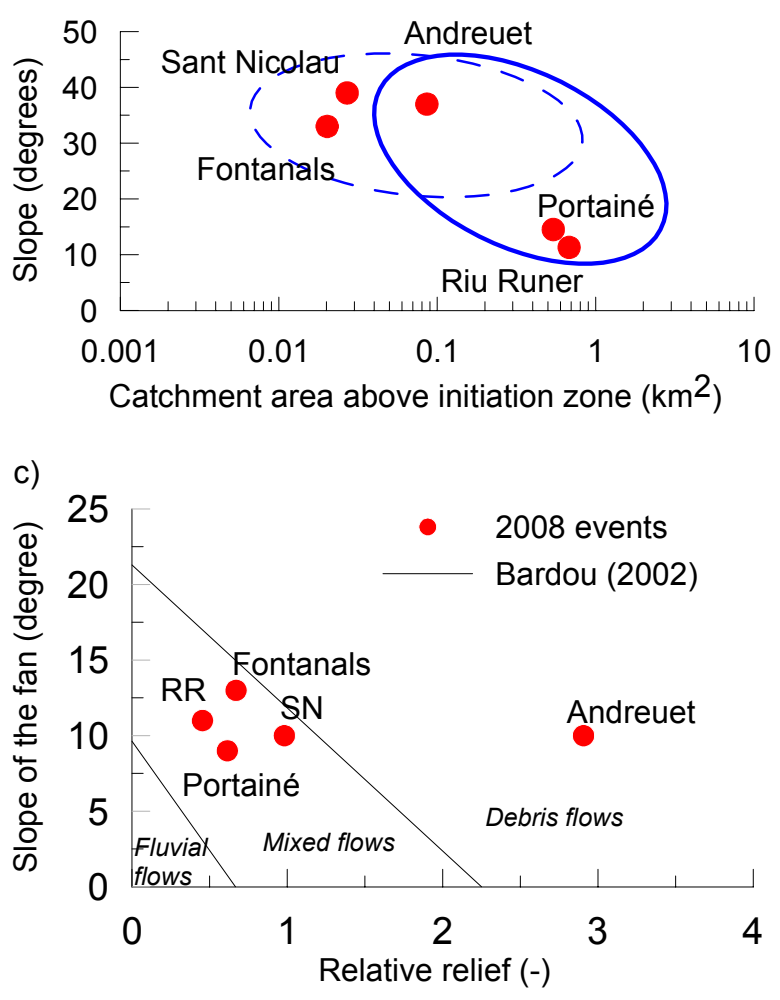

Fig. 4. Geomorphological relationships: (a) volume versus catchment area, (b) slope versus catchment area above initiation zone Channel erosion and slope instability clusters follow VAW (1992) and Zimmermann et al. (1997), and (c) slope of the fan versus relative relief (Melton, 1965).

Figure 4a shows a positive trend: the magnitude of debris flows increases at the same time as the catchment area. Moreover, it appears that all the events described in this study fit within the limits published by D'Agostino and Marchi (2001). It may seem that the geographical position of the catchment does not quantitatively influence volume versus catchment area relationship. Nevertheless, further investigation is needed to confirm this regional relationship be- cause of the large scatter of data. The hazard study of Pyrenean catchments could be greatly enhanced by the use of such a relationship. The determination of a catchment area could lead to a range in the preliminary estimation of the event's magnitude, and could pledge for an optimised mitigation.

When the slope at the initiation is plotted against the catchment area above this initiation zone, a negative correlation seems to emerge. VAW (1992) and Zimmermann et al. (1997) worked on this correlation for debris flows in the Swiss Alps, and defined and published two clusters of points shown in Fig. 4b. The first cluster gathers the events initiated by a slope failure. It lies at a small catchment area above the initiation zone $\left(<0.1 \mathrm{~km}^{2}\right)$ and at a rather large slope angle (over $27^{\circ}$ ). A second cluster is emphasized and includes both in-channel formed debris flows. Although overlapping, the clusters shown in Fig. 4b incorporate all described events. Only the Andreuet position remains ambiguous because it belongs to both clusters.

The difference in elevation of a catchment divided by the square root of its area was firstly mentioned by Melton (1965), and is referred to as the relative relief. Different authors have used it since, emphasizing the relationship between the catchment morphology and the characterisation of the process building up the fan (Jackson et al., 1987; Brochot and Marchi, 2000; Bardou, 2002). Here, we proposed the study of the relationship between the relative relief and the slope of the fan (Fig. 4c) in order to analyse, if both those factors were consistent in differentiating fluvial from debris flow fans (Kostaschuk et al., 1986). Limits found in Bardou (2002) are depicted. Catchments and fan, where the 2008 debris flows occurred, are shown in relation to these limits. It appears that only Andreuet catchment and fan fit within the debris flow zone that Bardou (2002) introduced; the other four are to be found in the mixed zone. The French Alps (Maurienne region) served as a base for the establishment of Bardou's limits, which have been edited comparing his Swiss dataset (Valais region) with that of Brochot and Marchi (2000). Undoubtedly limits have to be adapted for the Eastern Pyrenees.

All these results also show that the geomorphological study of catchments and of fans is not sufficient when investigating debris-flow impact on the landscape. Many parameters, regarding land use, geology, the occurrence of wild fires, for instance, should also be considered (Liu at al., 2002; Di Crescenzo and Santo, 2005).

\section{Rainfall analysis}

The rainfall analysis is performed introducing a description of previous studies carried out in the Spanish Eastern Pyrenees. Furthermore, the hyetographs of the rainfall data related to the five events studied are presented and analysed. Finally, the rainfall data are compared to the rainfall thresholds established in the literature. 
Table 2. Information on meteorological stations and rainfall characteristics.

\begin{tabular}{lccccc}
\hline & Riu Runer & Fontanals del Pui & Portainé & Andreuet & Sant Nicolau \\
\hline Meteorological station & Sant Julià de Lòria & Aixàs & Salòria & Bonaigua & Boi \\
Recording interval & $6 \mathrm{~min}$ & $10 \mathrm{~min}$ & $1 \mathrm{~h}$ & $30 \mathrm{~min}$ & $1 \mathrm{~h}$ \\
Altitude (m a.s.l.) & 865 & 1566 & 2445 & 2266 & 2540 \\
Distance to debris flow source area $(\mathrm{km})$ & 5.4 & 2.1 & 17.0 & 4.0 & 9.4 \\
Mean annual rainfall $(\mathrm{mm})$ & $850-900$ & $850-900$ & $950-1000$ & $1150-1200$ & $1000-1050$ \\
Total rainfall for debris flow trigger $(\mathrm{mm})$ & 64.4 & 31.5 & 40.7 & 40.0 & 30.9 \\
Duration rainfall $(\mathrm{h})$ & 3.3 & 4.5 & 6.5 & 9.0 & 7.0 \\
Rainfall peak intensity $(\mathrm{mm} / \mathrm{h})$ & 57.0 & 29.9 & 14.6 & 13.6 & 13.0 \\
\hline
\end{tabular}

\subsection{Previous studies}

Few rainfall thresholds for landslide occurrence on the south face of the Eastern Pyrenees can be found in literature. The following three studies have focussed on the upper Llobregat River Basin (Fig. 1b) and represent the most relevant background for the analysis of the five 2008 debris flows.

Corominas and Moya (1999) stated that debris flows and shallow slides in colluvial material and weathered rocks are initiated by a minimum of $190 \mathrm{~mm}$ of rainfall in $24 \mathrm{~h}$, regardless of the antecedent rainfall. Another condition was defined by the total rainfall amount exceeding $300 \mathrm{~mm}$ in 24-48 h. Regarding reactivations of mudslides and slides in clayey materials, they propose a rainfall amount of $40 \mathrm{~mm}$ in $24 \mathrm{~h}$ and $200 \mathrm{~mm}$ of antecedent precipitation.

Corominas et al. (2002) suggested the expression $I_{\mathrm{d}}=66.1 D_{\mathrm{d}}^{-0.59}$ as a rainfall threshold for reactivation of mudslides and mid-sized slides (where $I_{\mathrm{d}}$ stands for the rainfall intensity in $\mathrm{mm} /$ day and $D_{\mathrm{d}}$ is the rainfall duration in days).

Marco (2007) defined the critical rainfall for different types of mass movements (principally slides, debris flows and earth flows) as $51 \mathrm{~mm}$ in $24 \mathrm{~h}$ with the requirement of about $61 \mathrm{~mm}$ of antecedent rainfall. The expression standing for this threshold is given by $A c>24 D_{\mathrm{w}}+109$, in which $A c$ represents accumulated precipitation in millimetres and $D_{\mathrm{w}}$ the rainfall duration in weeks.

An important drawback for the application of these thresholds to our five debris flows is the fact that all of the proposed relationships were established by studying daily rainfall records. In addition, the rainfall episodes occurred during autumn or winter seasons regarding long-lasting rainfalls with a duration of more than one day, which normally cover a large geographic area and result from advective storms.

\subsection{Rainfall data analysis}

The information on the rainfall data and meteorological stations used in this study is listed in Table 2. The rainfall data recorded at the closest meteorological stations for every event were plotted in its respective hyetograph to find out their main characteristics and to get some insight into their temporal behaviour. Note that no rainfall occurred during at least 8 days before the events under study took place. The only exception is Sant Nicolau, where $70.8 \mathrm{~mm}$ precipitation was measured during the 4 days previous to the debris flow. Another interesting fact is that the Riu Runer and Fontanals del Pui events, $8.5 \mathrm{~km}$ away from each other, were triggered by the same storm happening on 1 August 2008.

The hyetographs (Fig. 5) depict that for the Riu Runer and Fontanals del Pui events, the rainfall peak intensity is reached very quickly (less than $1 \mathrm{~h}$ ) and subsequently the rainfall suddenly ceases. For the Sant Nicolau and Andreuet events, the maximum rainfall intensity is reached slowly (during $\sim 7 \mathrm{~h}$ ) and then the rainfall terminates in less than $2 \mathrm{~h}$. Meanwhile, for Portainé debris flow, the maximum rainfall is reached in one and a half hours, and rainfall decreases as time goes by (6h).

The five rainfall records can be summarised by two simple statements: 1) the hourly peak intensities range from 13 to $57 \mathrm{~mm} / \mathrm{h}$; and 2) the total rainfall amounts are between 31 and $64 \mathrm{~mm}$. Interpreting this information, several well-known limitations related to the analysis of landslidetriggering rainfalls should be considered such as site-specific meteorological and hydrological conditions or the distance between the debris-flow event and the rain gauge (Crosta, 1998; Aleotti, 2004; Guzzetti et al., 2007). Nevertheless, a preliminary hypothesis seems to be that the five debris flows studied herein were triggered by short and intense rainstorms. However, the role played by the antecedent rainfall should never be disregarded, like it happened in Sant Nicolau event.

\subsection{Comparison with rainfall thresholds}

The main annual rainfall of the different areas investigated ranges from 850 to $1200 \mathrm{~mm}$ (Table 2). The mean rainfall intensity - duration curves of the five debris flows were compared with two types of published thresholds: regional (Guzzetti et al., 2007) and the ones for the Eastern Pyrenees (Corominas and Moya, 1999; Corominas et al., 2002; Marco, 2007).

Figure 6 shows that only the relationship defined for Italy matches all the 2008 events. Considering the entire rainfall 

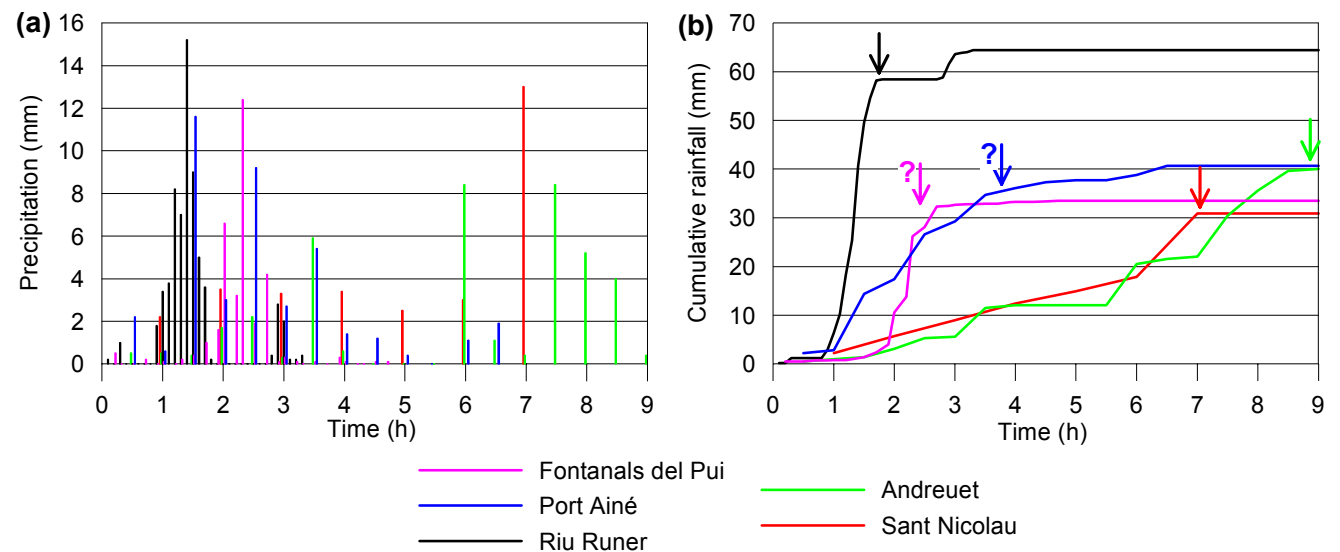

Fig. 5. Hyetographs (a) and cumulative rainfalls (b) of the debris flows studied. Arrows indicate an estimated debris flow time of occurrence. A question mark accompanies the arrow when this estimate relies on doubt.

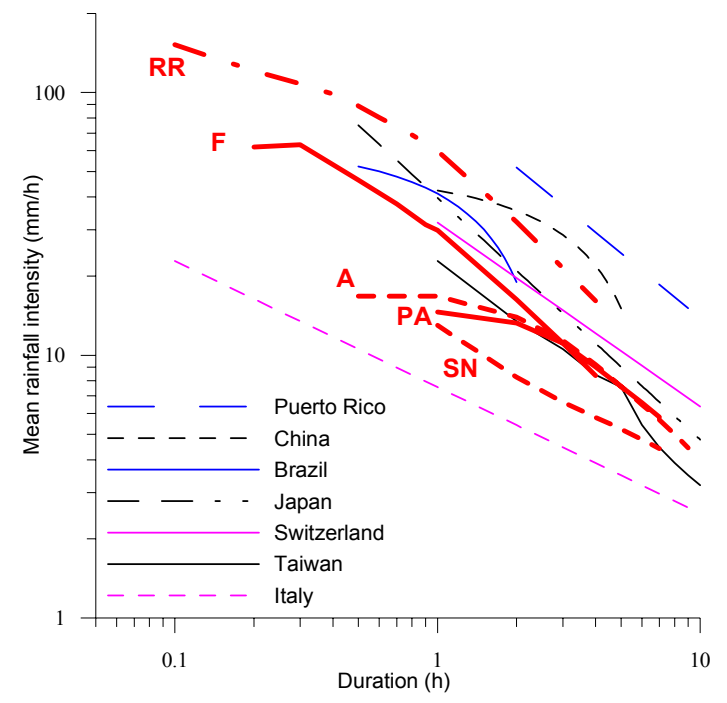

Fig. 6. Comparison between rainfall intensity-duration curves of the five debris flows analysed and regional scale thresholds (Guzzetti et al., 2007).

evolution, the Riu Runer debris flow fits almost all the relationships. In contrast, the other events remain unpredictable by most relationships.

Regarding the thresholds defined for the Eastern Pyrenees, Corominas and Moya's (1999) threshold does not fit the five debris flows studied, because the total rainfall amount for each one was less than $190 \mathrm{~mm}$. Likewise Marco's (2007) threshold does not match, because neither the event rainfall nor antecedent rainfall were reached. Finally, the published threshold of Corominas et al. (2002) could not apply to our study because it was obtained for long-lasting rainfalls (more than $24 \mathrm{~h}$ ); the events studied in this paper were caused by short duration storms (less than $10 \mathrm{~h}$ ).

In a nutshell and according to the previous results and analyses, it can be assumed that the 2008 debris flows were triggered by short duration-high intensity rainfalls, all of them happening during the summer season. Consequently, they do not fit the existing thresholds established for the Eastern Pyrenees. Thus, it is necessary to establish new thresholds related to convective summer storms using at least hourly rainfall data. Such detailed rainfall records are essential information in order to get appropriate critical rainfall characteristics that explain the triggering of debris flows as during the summer 2008.

\section{Runout analysis}

The runout analysis of the different events was carried out by applying two methodologies. First, the runout data of all events were compared with published empirical relationships. Then, one selected event was analysed more comprehensively, applying numerical modelling in order to investigate its flow behaviour.

\subsection{Empirical runout prediction}

Empirical relationships are very common methods to approximate the maximum runout distance of debris flows and other types of mass movements. Here, we compare the mobility of the 2008 Pyrenean debris flows using the ratio between the vertical drop, $H$, and the horizontal projection of the total runout distance, $L$ (e.g. Rickenmann, 1999). This ratio $H / L$ can also be called reach angle, $\alpha$, or "Fahrböschung" and is linked to the debris-flow volume, $V$.

The runout data of the 2008 debris flows are illustrated in Table 1 and confirm the trend that larger volume generally induces a higher mobility, which translates into a lower $H / L$ ratio. Subsequently, Fig. 7 shows the 2008 data in a standard $H / L$ vs. $V$ graph comparing them with three different types of records previously published. Firstly, the runout data of 92 debris flows occurred in the Eastern Pyrenees were plotted. Most of these events were triggered during the 1982 flood episode (see Hürlimann and Baeza, 2002 for more details). Secondly, the empirical relationship proposed by Corominas (1996) was drawn. The lower and upper 


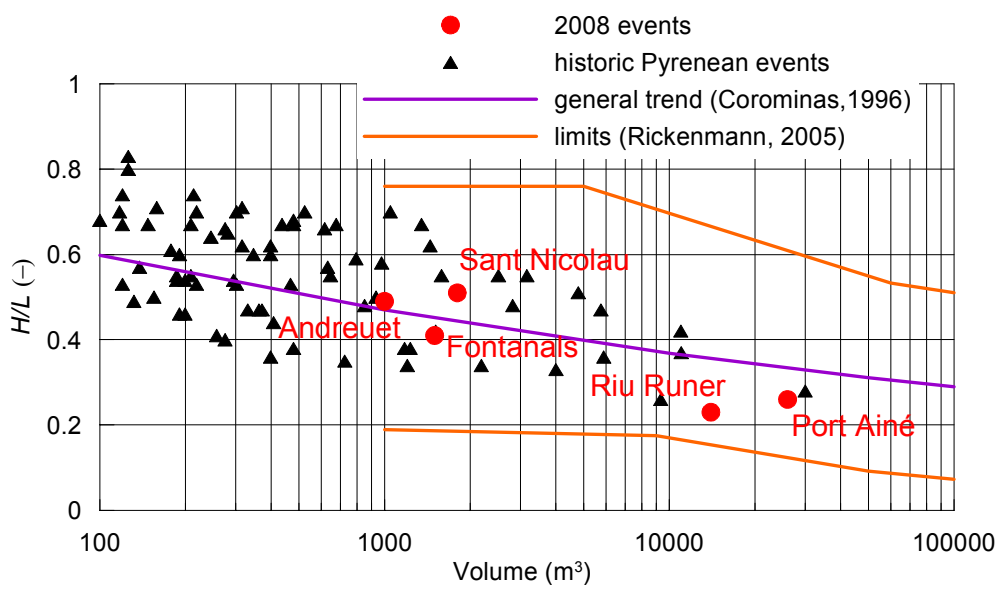

Fig. 7. Mobility comparison of 2008 debris flows with other published data from the Eastern Pyrenees and worldwide records.

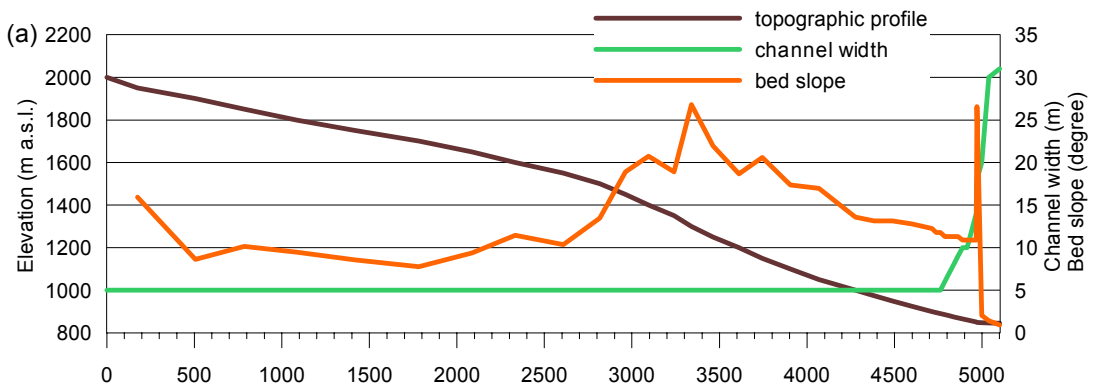

(b)

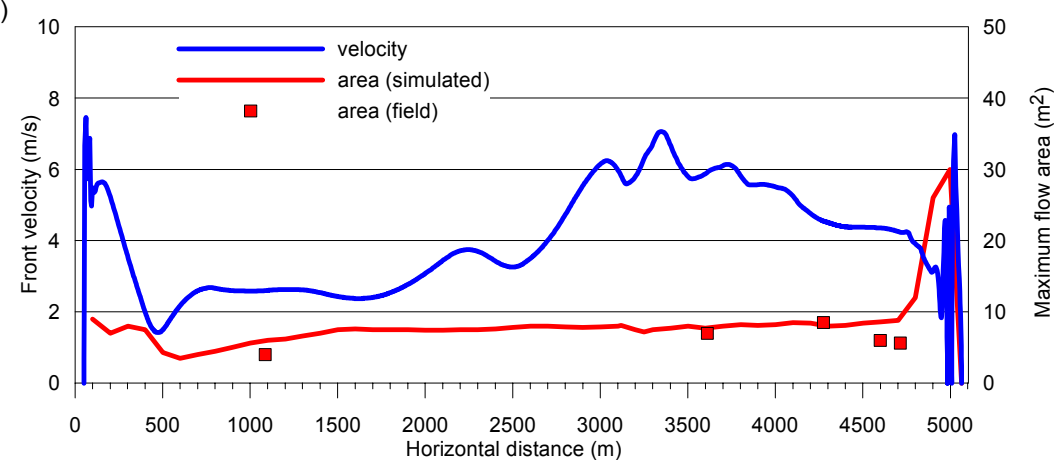

Fig. 8. Numerical simulation results of the Riu Runer event. (a) Longitudinal profile, channel width and bed slope used in the simulation. (b) Results obtained by DAN for $C=10 \mathrm{~m}^{1 / 2} / \mathrm{s}$ and $\mu=0.1$, showing the variation of the front velocity and the maximum flow area. Squares represent cross-section areas.

limits of the data published in Rickenmann (2005) were also illustrated. The comparison of the 2008 debris flows with the data from other published events indicate, that: 1) the Riu Runer and Portainé events are one of the largest debris flows that have recently been observed in the Eastern Pyrenees, 2) all five events are located in the mobility range defined by empirical relationships and published data.

\subsection{Numerical simulation}

The Riu Runer event was selected to carry out a detailed analysis of the dynamic behaviour by numerical modelling. This back-analysis may lead to the answering of questions such as: Can Pyrenean debris flows be simulated by similar rheologic models and parameter values like the ones from different mountain ranges? Which were the maximum velocities and discharges of the debris flow? Are they comparable to events from other mountain ranges?

The 1-D, finite difference code "DAN" has been used (Hungr, 1995), in which necessary input parameters include the topographic profile, the channel shape and width, rheological parameters, and the initial volume. Additionally, the scour rate can be incorporated, which was an important fact since entrainment was a significant process in the Riu Runer event. 
The rheological law assumed in the model runs was the Voellmy fluid model. This decision is supported by the fact that recent back-analyses of Andorran debris flows have shown that the Voellmy fluid flow law provided reasonable results (Hürlimann et al., 2006), and that the Voellmy fluid model is widely considered to be a suitable law for granular debris flow (e.g. Naef et al., 2006). The two necessary parameters for this rheological model are dry friction coefficient, $\mu$, and turbulent Chezy-like friction term, $C$.

The sensitivity analysis of the two rheological parameters was performed for the following assumptions, which are necessary to simplify the real process for the simulations. An initial volume of $770 \mathrm{~m}^{3}$ was released at an altitude of about $2000 \mathrm{~m}$ a.s.l., and then a constant entrainment rate of $4 \mathrm{~m}^{3} / \mathrm{m}$ was assumed, which produced a final volume at the fan of about $14000 \mathrm{~m}^{3}$. The channel width upstream of the fan was defined by a constant value of $5 \mathrm{~m}$ and an increasing width up to $30 \mathrm{~m}$ in the accumulation area.

The sensitivity analysis of the two rheological parameters was performed comparing simulated values with field observations of both the maximum runout distance and the flow areas or inundated area. A common problem of two-parameter analysis represents the fact that various combinations of $\mu$ and $\mathrm{C}$-values are possible for reasonable matches of simulation results with field observations. Finally, the best-fit simulation results were obtained by a $\mu$-value of 0.1 and a Cvalue of $10 \mathrm{~m}^{0.5} / \mathrm{s}$. Figure 8 illustrates the front velocity and maximum flow area along the flow path and shows that the flow was rather slow in the upper smoother part, while velocity increased up to $7 \mathrm{~m} / \mathrm{s}$ in the steepest section. Maximum flow discharge in this section was about $55 \mathrm{~m}^{3} / \mathrm{s}$, while flow discharge and velocity decreased to about $35 \mathrm{~m}^{3} / \mathrm{s}$ and $4 \mathrm{~m} / \mathrm{s}$, when entering the fan. In the accumulation area, the flow stopped and remobilised several times, which is represented by the fluctuations at the final section of the flow path.

The comparison of the values of the rheological parameters and the data acquired from the back-analyses of other Andorran events (Hürlimann et al., 2006) shows that, in the case of the Runer River, the values of the dry friction coefficient $\mu$ are a bit smaller, while the $\mathrm{C}$-value matches well with the rest of results. This fact may support the hypothesis of some eyewitnesses that indicate that high water content in the flow is likely to reduce the frictional component (EUROCONSULT ANDORRA S.A., personal communication, 2008). Nevertheless, both rheological parameters match the value ranges published in a recent review on debris flow parameters (Hürlimann et al., 2008). In addition, maximum flow velocity, flow area and discharge observed in the backanalysis coincide with the characteristics of events analysed in other studies (e.g. Rickenmann, 1999), although the maximum discharge of the Runer River event was smaller than assumed for granular debris flows. This fact may again support the hypothesis that the event may have included a higher liquid concentration.

\section{Conclusions}

Research on debris flow has only been performed marginally in the Pyrenees and associated hazard has been mostly neglected. That is why we proposed here the study of five debris flows, which occurred in 2008 in the Eastern Pyrenees. The susceptibility, trigger and dynamical behaviour represent the investigation's scope.

Landslide triggered debris flows encountered in 2008 display a high slope at the scar (over $25^{\circ}$ ) and a little catchment area above the initiation zone (less than $0.1 \mathrm{~km}^{2}$ ) relationship. In-channel generated debris flows, on the contrary, show a large catchment area above the initiation zone (close to $1 \mathrm{~km}^{2}$ ) and a lower slope angle (less than $15^{\circ}$ ). There also seems to exist a positive correlation between catchment area and debris flow volume. The distinction of both debris-flow types is, however, hardly achievable when only taking into account simple geomorphological parameters such as relative relief and the fan's slope. Finally, the fact that data from the Eastern Pyrenees fit the relationships validated for the European Alps, tends to pledge for an interregional standardization of the susceptibility analysis of such hazards.

For the Eastern Pyrenees only thresholds, considering long-lasting rainfall usually occurring in autumn/winter, have been established. However, high intensity and short duration storms are involved here in the studied events. For this reason, the most relevant aspect to consider is the rainfall peak intensity $(\mathrm{mm} / \mathrm{h})$. Therefore, new thresholds regarding short duration convective storms must be defined using this study's results as a starting point, as well as the role played by antecedent rainfall.

Riu Runer being a recent outstanding debris flow for the Eastern Pyrenees proved to be a good event for a 1-D simulation. It appeared that the Voellmy fluid rheology fitted the flow behaviour. The maximum velocity obtained reaches $7 \mathrm{~m} / \mathrm{s}$ and the maximum flow discharge was about $55 \mathrm{~m}^{3} / \mathrm{s}$. Both are in a coherent range when compared to other debris flows presented in the literature.

The results are promising and widen the scope of applicability of relationships defined in the literature so far. More examples are, however, recommended to refine the results presented.

Acknowledgements. This research was supported by the Spanish Ministry of Science and Innovation, contract CGL2008-00299/BTE and the EC FP7 project IMPRINTS, contract ENV-2008-1-226555. Rainfall data for Andorra was provided by EUROCONSULT ANDORRA SA and Andorran Civil Protection.

Edited by: M. Arai

Reviewed by: three anonymous referees 


\section{References}

Aleotti, P.: A warning system for rainfall-induced shallow failures, Eng. Geol., 73, 247-265, 2004

Baeza, C. and Corominas, J.: Assessment of shallow landslide susceptibility by means of multivariate statistical techniques, Earth Surf. Proc. Land., 26, 1251-1263, 2001.

Bardou, E.: Methodologie de diagnostic des laves torrentiells sur un bassin versant, Ecole Polytechnique de Lausanne, thèse doctorale, 188 pp., 2002 (in French).

Bathurst, J. C., Burton, A., Clarke, B. G., and Gallart, F.: Application of the SHETRAN basin-scale, landslide sediment yield model to the Llobregat basin, Spanish Pyrenees, Hydrol. Process., 20, 3119-3138, 2006.

Brochot, S. and Marchi, L.: Les cônes de déjection torrentiels dans les Alpes françaises. Morphométrie et processus de transport solide torrentiel, Revue de géographie alpine, 88, 23-38, 2000 (in French).

Coussot, P. and Meunier, M.: Recognition, classification and mechanical description of debris flows, Earth-Sci. Rev., 40, 209 227, 1996

Corominas, J.: The angle of reach as a mobility index for small and large landslides, Can. Geotech. J., 33(2), 260-271, 1996.

Corominas, J. and Moya, J.: Reconstructing recent landslide activity in relation to rainfall in the Llobregat River basin, Eastern Pyrenees, Spain, Geomorphology, 30, 79-93, 1999.

Corominas, J., Moya, J., and Hürlimann, M.: Landslide rainfall triggers in the Spanish Eastern Pyrenees, Editrice, Mediterranean Storms, Proceedings of the 4th EGS Plinius Conference held at Mallorca, Spain, 2002.

Crosta, G.: Regionalization of rainfall thresholds: an aid to landslide hazard evaluation, Environ. Geol., 35, 131-145, 1998.

Cuadrat, J. M. and Pita, M. F.: Climatología. Ediciones Cátedra, Madrid, España, 496 pp., 1997.

D'Agostino, V. and Marchi, L.: Debris Flow Magnitude in the Eastern Italian Alps: Data Collection and Analysis, Phys. Chem. Earth Pt. C, 26(9), 657-663, 2001.

Di Crescenzo, G. and Santo, A.: Debris slides-rapid earth flows in the carbonate massifs of the Campania region (Southern Italy): morphological and morphometric data for evaluating triggering susceptibility, Geomorphology, 66, 255-276, 2005.

ECORS Pyrenees Team: The ECORS deep reflection seismic survey across the Pyrenees, Nature, London, 331, 508-510, 1988

Fitzgerald, P. G., Muñoz, J. A., Coney, P. J., and Baldwin, S. L.: Asymmetric exhumation across the Pyrenean orogen: implications for the tectonic evolution of a collisional orogen, Earth Planet. Sc. Lett., 173(3), 157-170, 1999.

Gallart, F. and Clotet, N.: Some aspects of the geomorphic processes triggered by an extreme rainfall event: The November 1982 flood in The Eastern Pyrenees, Catena Supp., 13, 79-95, 1988.

Guzzetti, F., Peruccacci, S., Rossi, M., and Stark, C. P.: Rainfall thresholds for the initiation of landslides in central and southern Europe, Meteorol. Atmos. Phys., 98(3-4) , 239-267, doi:10.1007/s00703-007-0262-7, 2007.

Hungr, O.: A model for the run-out analysis of rapid flow slides, debris flows, and avalanches, Can. Geotech. J., 32, 610-623, 1995.

Hungr, O., Evans, S. G., Bovis, M. J., and Hutchinson, J. N.: A review of the classification of landslides of the flow type, Environ. Eng. Geosci., 3, 221-238, 2001.
Hürlimann, M. and Baeza, C.: Analysis of debris-flow events in the eastern Pyrenees, Spain, 1st European Conference on Landslides, Balkema, Prague, 213-220, 2002.

Hürlimann, M., Copons, R., and Altimir, J.: Detailed debris flow hazard assessment in Andorra: A multidisciplinary approach, Geomorphology, 78, 359-372, 2006.

Hürlimann, M., Rickenmann, D., Medina, V., and Bateman, A.: Evaluation of approaches to calculate debris-flows parameters for hazard assessment, Eng. Geol., 102, 152-163, 2008.

ICC, Institut Cartogràfic de Catalunya: Mapa geològic de Catalunya 1:250 000, Barcelona, 2003.

Jackson, L. E., Kostaschuk, R. A., and MacDonald, G. M.: Identification of debris flow hazard on alluvial fans in the Canadian rocky mountains, Eng. Geol., 7, 115-124, 1987.

Kostaschuk, R. A., MacDonald, G. M., and Putnam, P. E.: Depositional process and alluvial fan-drainage basin morphometric relationships near Banff, Alberta, Canada, Earth Surf. Proc. Land., 11, 471-484, 1986.

Liu, X., Yue, Z. Q., Tham, L. G., and Lee, C. F.: Empirical assessment of debris flow risk on a regional scale in Yunnan Province, southwestern China, Environ. Manage., 30, 249-264, 2002.

Lynn, G.: Macrogeomorphology and Erosional History of the PostOrogenic Pyrenean Mountain Belt, Ph.D. thesis, The University of Edinburgh, Edinburgh, 388 pp., 2005

Marco, P. L.: Determinació de llindars de pluja desencadenants d'esllavisades a Catalunya, Tesina de Grau, Departament d'Enginyeria del Terreny, Cartogràfica i Geofísica, Universitat Politècnica de Catalunya, Barcelona, Espanya, 150 pp., 2007 (in Catalan).

Martín, V. J. and Olcina, C. J.: Climas y Tiempos de España, Alianza Editorial, S.A., Madrid, España, 258 pp., 2001.

Melton, M. A.: The morphologic and paleoclimatic significance of alluvial deposits in southern Arizona, J. Geol., 73, 1-38, 1965.

Muñoz, J. A.: Evolution of a continental collision belt: ECORSPyrenees crustal balanced cross-section, in: Thrust Tectonics, edited by: McClay, K. R., Chapman and Hall, 235-246, 1992.

Naef, D., Rickenmann, D., Rutschmann, P., and McArdell, B. W: Comparison of flow resistance relations for debris flows using a one-dimensional finite element simulation model, Nat. Hazards Earth Syst. Sci., 6, 155-165, doi:10.5194/nhess-6-155-2006, 2006.

Rickenmann, D.: Empirical relationships for debris flows, Nat. Hazards, 19, 47-77, 1999.

Rickenmann, D.: Run-out prediction methods, in: Debris-flow Hazards and Related Phenomena, edited by: Jakob, M. and Hungr, O., Springer, Berlin, 305-324, 2005.

Santacana, N., Baeza, B., Corominas, J., Paz, A. D., and Marturiá, J.: A GIS-Based Multivariate Statistical Analysis for Shallow Landslide Susceptibility Mapping in La Pobla de Lillet Area (Eastern Pyrenees, Spain), Nat. Hazards, 30, 281-295, 2003.

Teixell, A.: Crustal structure and orogenic material budget in the west-central Pyrenees, Tectonics, 17, 395-406, 1998.

VAW: Murgänge 1987: Dokumentation und Analyse, in: Versuchsanstalt für Wasserbau, Hydrologie und Glaziologie (VAW), No. 97.6, ETH Zürich, unpublished, 620 pp., 1992.

Zimmermann, M., Mani, P. Gamma, P., Gsteiger, P., Heiniger, O., and Hunziker, G.: Murganggefahr und Klimaänderung ein GIS-basierter Ansatz, in: Schlussbericht NFP 31, vdf-ETH Zürich, Switzerland, 161 pp., 1997 (in German). 